Article

\title{
Tourism as an Approach to Sustainable Rural Development in Post-Socialist Countries: A Comparative Study of Serbia and Slovenia
}

\author{
Marko D. Petrović ${ }^{1,2, *}$, Aleksandra Vujko $^{3}$ (D), Tamara Gajić ${ }^{3}$, Darko B. Vuković ${ }^{1,4}$ (D), \\ Milan Radovanović ${ }^{1,2}$, Jasmina M. Jovanović ${ }^{5}$ and Natalia Vuković ${ }^{6}$ \\ 1 Geographical Institute “Jovan Cvijić” SASA, Djure Jakšića 9, 11000 Belgrade, Serbia; \\ d.vukovic@gi.sanu.ac.rs (D.B.V.); m.radovanovic@gi.sanu.ac.rs (M.R.) \\ 2 Institute of Sports, Tourism and Service, South Ural State University, 76 Lenin Avenue, \\ Chelyabinsk 454080, Russia \\ 3 Novi Sad Business School, Vladimira Perića Valtera 4, 21000 Novi Sad, Serbia; \\ aleksandravujko@yahoo.com (A.V.); gajic_tamara@yahoo.com (T.G.) \\ 4 Department for Finance, St. Petersburg School of Economics and Management, National Research University \\ Higher School of Economics, Kantemirovskaya St. 3A, Office 331, Sankt Petersburg 194100, Russia \\ 5 Faculty of Geography, University of Belgrade, Studentski trg 3/III, 11000 Belgrade, Serbia; \\ jasminaj121sunce@gmail.com \\ 6 Graduate School of Economics and Management, The Ural Federal University Named after the First \\ President of Russia B. N. Yeltsin, 19 Mira St., Yekaterinburg 620002, Russia; shpak17121978@gmail.com \\ * Correspondence: m.petrovic@gi.sanu.ac.rs; Tel.: +381-64-174-8257
}

Received: 2 December 2017; Accepted: 24 December 2017; Published: 28 December 2017

\begin{abstract}
The research deals with the sustainable development of the Serbian and Slovenian countryside, under the influence of tourism progress. The article identifies the main rural tourism competitiveness in Serbia and Slovenia, as one of the essential factors of rural development in both countries, analyzing the main contributions and making a series of proposals to guide the future research agenda. The aim of the paper is to clarify around one obviously defined objective- to point out the competitiveness of sustainable rural tourism in typical post-socialist settings. The data for this study were collected using the Integrated Model of Destination Competitiveness to observe Serbian and Slovenian competitiveness in tourism. Determinants were assessed using a survey evaluating four demanding factors and 20 supporting factors, based upon a five-point Likert Scale. The results indicated that the friendliness of residents towards visitors, easy communication between them, together with quality of infrastructure and health facilities show the highest level of statistical correlation. These are the main propositions to start an initiative for the authorities in local communities to actively participate in sustainable rural development. The findings provide tourism stakeholders with relevant respondents' perceptions pertaining to the tourism development in non-urban areas.
\end{abstract}

Keywords: countryside's development; sustainable tourism; competitiveness; transitional societies; rural economy

\section{Introduction}

At the beginning of 1990s, the former Yugoslav countries started with disintegration and territorial transformation. Contrary to tourism in the socialist period that was designated as totally rigid, tourism of post-socialist period became the emissary of privatization and market liberalization. During this period, tourism has become an integral element of diverse rural economies, by 'using' the countryside and natural resources as its significant basis [1]. A rapidly changing in rural environment 
was characterized by the deep changes into the service sector, involving tourism. The most of the ex-Yugoslavia states possesses exceptional rural resources for the development of numerous aspects of "green" economies, including sustainable tourism in the countryside (favorable conditions of the preserved environment, with mild climate, pristine waterflows, clean air, and rich biodiversity). The visitors that are interested in that kind of activity can join their hosts in doing agricultural works. A great number of villages are situated near the important cultural-historic monuments, which the visitors can include in an organized visit. According to some authors [2,3], the use of traditional rural buildings for tourism affirmation is considered sustainable when the main reference is made to the protection of the local environment and to encourage tourists to visit the same destination again. Exceptional cultural values can be found in the facilities of traditional architecture, as well as the products of old crafts, through which the local heritage and tradition can be learnt about. This variety of tourist resources and the richness of cultural heritage are especially enriched with exceptional hospitality and cordiality of the locals.

Rural tourism is given special priority in National Sustainable Development Strategy in Serbia from 2007 [4], since it is observed as a high potential sector with vertical institutional structure supporting its development. About 1000 rural households have been registered, offering hospitality services in Serbian countryside. Rural tourism is a primary activity for about 300 household members, which comprises about 8000 beds. Average length of stay in a household is 2.8 days [5]. It is evident that the number of households constantly increases. Nevertheless, rural tourism development in Serbia would be enhanced by the statistical analysis of this tourism form and its offer.

On the other hand, well-organized rural tourism in Slovenia started at the beginning of the 1970s [6-8]. The country has undergone a serious process from the foundation of advisory services, establishing technical conditions and categorization, engaging experts to establishing associations, creating original rural tourism product, training of the locals, and many promotional activities $[9,10]$. At present, this tourism branch is compliance with domestic and European Union's laws [11]. The number of households that offer services in rural tourism in this country is about 600 . There are approximately 370 farms offering accommodation (with total of 4342 tourist beds in 2012), and average length of stay in a household is 3.7 days [12,13]. Tourism is recognized as one of the main areas of great opportunity for Slovenian rural economy, and The Association of Tourist Farms of Slovenia and the Slovenian Tourist Board provide excellent marketing tools to attract more visitors.

Sustainable tourism can enhance the identity of the entire country, because it is strongly related to ways of local production, locals' life, cultural celebration, heritage [14-16], and natural attractions [17] in rural or (peri-)urban settings. Moreover, this type of tourism is an alternative of great interest for different segments of tourists whose preferences include the sustainability of tourist spaces when planning their trips. During the visit to a destination, visitors can experience the attractions of the area, and it is likely that a positive experience will influence the likelihood of a return visit [18]. This reverence for the environmental issue and the distinction of destinations implies one of the main aspects of the sector's growth [19]. Moreover, Campón-Cerro et al. [20] stated that rural ambiences are undergoing an important transformation, where some service sectors (e.g., travel industry and food industry) achieved key roles in rural economy. As a result, they need to implement innovative strategies, to compete in global markets, and to develop sustainable tourism development in rural conditions.

In order to point out the competitiveness of rural tourism in two observed countries, the authors applied methodology firstly developed by Dwyer and Kim [21]. According to these researchers, competitive advantage relates to destination appeal, which "must be superior to that of the alternative destinations open to potential visitors" (p. 369). The main aim of this study is to point out the competitiveness of sustainable rural tourism in the observed countries. In order to provide the research aim, it would be necessary to answer on the following question: What are the main competitive advantages of the travel industries in the countryside of these two countries? Moreover, the authors compared the competitiveness of two mentioned destinations because these countries were former 
states of the Republic of Yugoslavia until 1991, had similar economic, cultural and social conditions in the past, and shared the analogous transitional situations of the rural settings. These conditions, in combination with the deep social changes that were caused by the permanent land restitution process and finally produced a new agrarian era of rural society. However, the analyzed countries are assumed to have different level of competitiveness of rural development and sustainable tourism and to encounter the same obstacles [12], while striving to achieve better competitive position.

The text will involve an overview on rural tourism situations in some selected non-western European countries passed through similar economic and social transformation of rural settings, so called CEEC's countries. Furthermore, the application of Dwyer and Kim's [21] Integrated model of destination competitiveness will be tested on the observed two countries, including both supporting and demanding factors. The main findings gained by statistical correlation and descriptive statistical analysis will be presented in detail, accompanying adequate discussion. The conclusion's remarks will be provided with the aim to show contribution of the paper's results and the potential limitations during the research process.

\section{An Overview on Rural Tourism in Transitional Societies}

In contemporary studies on the development of the international trends in travel industry, rural tourism has raised as its increasing and relevant segment. According to Lane and Kastenholz [22], this type of tourism was recognized by local communities, as well as local municipalities, as an important economic activity that had many manageable challenges and regeneration utilities in rural surroundings. Rural tourism was not strongly based on property development, but it was created largely by revalorizing existing properties and heritage potentials as rural tourist attractions and accommodation facilities. This activity can be developed locally with participation from small businesses to the local municipalities. It frequently provides a base for the local businesses that might not otherwise be in rural communities because of their small populations. Moreover, rural tourism particularly helps both types of small businesses in rural areas: those that are directly involved in tourism (e.g., farm-stays, tour guides) and those indirectly involved in tourism business (e.g., stores, local transportation companies) [23]. According to the same authors, rural tourism can be developed with relatively little capital and training. On the other side, Hall [24] evaluated current issues and the development of rural tourism in southeastern (post-communist) Europe, highlighting the fact that "where rural tourism flourishes, however, it may actually be despite rather than because of government action" (p. 6), meaning that most of these countries (incl. Serbia and Slovenia) have been unable or unwilling to seriously invest in the travel industry. Together with this, he claimed that small scale community-based projects have emerged based on European Union funding, but without purposeful guidance and coordination these tend to be fragmented and may only lead to short-term results. Moreover, Sharpley [25] stated that the development costs when compared to returns are very high in rural tourism.

The operating competitive environment of the destination $[21,23]$ is also present in the studies of the development of rural destinations. First, the competitive environment of the rural stakeholders may refer to such success conditions as good local leadership, support and participation of rural municipalities, sufficient funds for tourism development, good convention, and widespread community support for tourism development. Second, the strategies of the destinations' stakeholders, including cooperation [21], may refer to the strategic planning of a complete tourism package, cooperation between businessmen and local leadership, and coordination between rural tourism entrepreneurs [23]. The last one involves the capabilities of destination companies [21], which seems to be the key to the other topics in rural surroundings.

Actually, after the demise of socialism in 1989, rural areas in the Central and Eastern European Countries (CEECs) entered a transition phase in which all spheres of economic and social life were transformed to emulate the western market-oriented model [26]. According to some researchers [27-29], rural areas passed through a deep and painful process of reorientation and adjustment. Followed by 
the subsequent transitory drop of almost all macroeconomic indicators (gross domestic product-GDP, employment, standard of living, etc.), the European socialist countries, such as Serbia and Slovenia, were forced to introduce rigorous reforms in rural surroundings [30-35].

As a result of the breakdown of communist farmsteads, coupled with the transition toward a market economy, many societies faced deep economic crisis in rural areas [27]. Agricultural structures were often uncompetitive and subject to market privatization and restructuring [26]. According to Mikulcak et al. [27], an important role in Romanian society, e.g., playing de-collectivization and a lengthy land restitution process. This is the reason, among others, why the country's farm structure is strongly polarized and fragmented-with more than $70 \%$ of rural inhabitants farming on less than two hectares, and only 2\% of holdings exceeding 10 hectares. Petrick and Gramzow [26] analyzed how the three governance mechanisms state, market, and community interacted to provide public goods in a rural, Eastern European setting. According to the same authors, Poland had many key problems, summarized as follows: (a) there was a considerable and increasing income gap between urban and rural areas, (b) small-scale farm structures and lacking off-farm income generation alternatives prevailed in many regions, implying high open or hidden unemployment, (c) the rural population generally displayed a low level of formal education, (d) basic technical infrastructure, such as transport, electricity, as well as water and sewage networks, was lacking or dysfunctional, (e) there was a low level of civic activity, also described as a lack of social capital. Moreover, the transition in the former Czechoslovakia occurred in one of the most centralized economic systems in the former eastern bloc. The same authors have stated that "there were struggles not only between different social groups intent on controlling the tourism industry, but also territorially, leading to the partition of the country in 1993 into the independent Slovak and Czech republics" [31] (p. 38). A quite similar situation was in rural ex-Yugoslav countries: Serbia and Slovenia.

After 1989, the Central and Eastern European Countries' (CEECs) tourism became increasingly subject to globalization. Rural tourism presents an obvious way for the CEECs' countries to project a new identity to the international community (and particularly Western Europe), and to affirm their status as post-socialist democracies [30]. Nowadays, rural tourism has powerful advantages in the international tourism market, as it has already played a key role in a countryside that has been socially, culturally and economically depressed [36-38]. Moreover, it becomes truly relevant aspect of the European tourism offer, which is evident in the total number of 200,000 well-known registered service providers in rural tourism on this continent, with more than 2000 beds [39]. Reducing traditional subsidies for agriculture makes rural tourism more and more important as a key form of diversification, which supports economically viable local communities. In Serbia, as well as in Slovenia, sustainable rural tourism is an important factor in multifunctional rural development [28,29,40-42]. Even more, Knickel and Renting [40] underlined the fact that "rural development consists of a wide variety of new activities, such as the production of high quality and region-specific products, nature conservation and landscape management, agritourism, and the development of short supply chains. The number and variety of new activities is, in reality, much larger" (p. 513). Changing the social, economic, and political system in Serbian and Slovenian rural areas at the very beginning of the new millennium also marks a new era in the development of sustainable rural tourism. This form should be one of the main promoters of the tourist offer and the factor of integral development of rural areas in the Serbian countryside [38], including a very similar situation in the Slovenian rural environment. Regarding the foregoing, it can be stated that the new socio-economic circumstances after the change of the communist regime have created new social conditions, in almost all of the CEECs' countries, involving both observed countries.

\section{Materials and Methods}

The authors applied the Integrated model of destination competitiveness, created by Dwyer and Kim [21] to territories of selected countries. This model has been previously employed in similar recent case-studies [12,43-46]. The model was deemed as the most appropriate scale for this 
study, because it provides tourism stakeholders and researchers insight pertaining what is needed to identify what changes are essential to improve (rural) tourism competitiveness.

The original model was conducted in the form of survey questionnaire that was divided into several economic performance indicators, i.e., main determinants of destination competitiveness [21]. Those are following: 1. Endowed Resources; 2. Created Resources; 3. Supporting Factors; 4. Destination Management; 5. Situational Conditions; 6. Demand Factors; and, 7. Market Performance Indicators (pp. 400-405). Modification of the original model has been developed for the purposes of this paper, and only two factors have been presented based on 24 indicators (Supporting Factors and Demand Conditions). The selected 24 indicators, as identified by Dwyer and Kim [21], are appropriate for measuring destination competitiveness in specific rural conditions of Serbia and Slovenia. We wanted to manage the picture showing how demanding factors actually corelates with supporting factors of tourism development in the observed rural settings. Then, a set of those indicators was created in the form of the statements conducted in the research. According to Mulec and Wise [47], there is no single set of competitiveness indicators that applies to all destinations at all times. Therefore, it must be noted that in any element of destination competitiveness, various indicators may be employed.

The results that are presented in the following section display mean values and standard deviations for each indicator. Indicators with mean values greater than 3.00 are regarded as competitive. The research has used local/national stakeholders to collect data.

The questionnaires were gathered from January to October 2017 in the territories of Serbia and Slovenia (Figure 1), as the extension of the previous research in Serbia and Eastern Slovenia conducted by the first three authors of this paper [48]. The researcher decided to conduct the questionnaire using non-probability convenience sample. The research sample was made out of tourism stakeholders on the supply side. Some of the questionnaires were self-directed, others were sent by emails.

Respondents were selected between Serbian and Slovenian stakeholders in different branches of tourism, including managers of travel agencies, private rural accommodations, tourist organizations, traditional farmsteads, and restaurants in rural destinations (Table 1). A total of 400 respondents were asked to rate the items, but 342 respondents had marked them correctly: 133 Slovenian participants and 209 Serbian participants. The respondents were marked competitiveness on a five-point Likert Scale for all 24 indicators, ranging from (1) Not competitive; (2) Partially competitive; (3) No opinion; (4) Competitive; and, (5) Strongly competitive. The poll was anonymous, i.e., the names of the examinees were not relevant for the selected data. Their socio-demographic characteristics are shown in detail in Table 2.

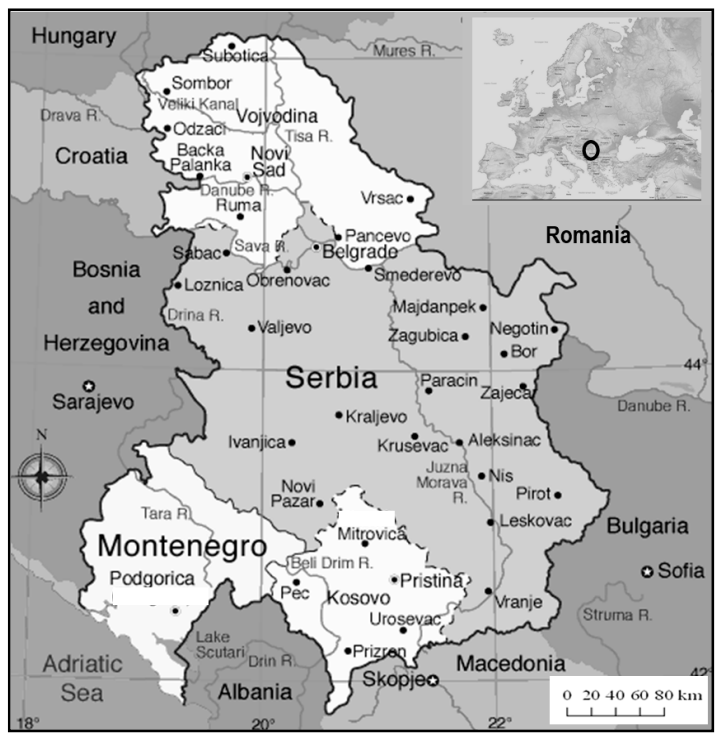

(a)

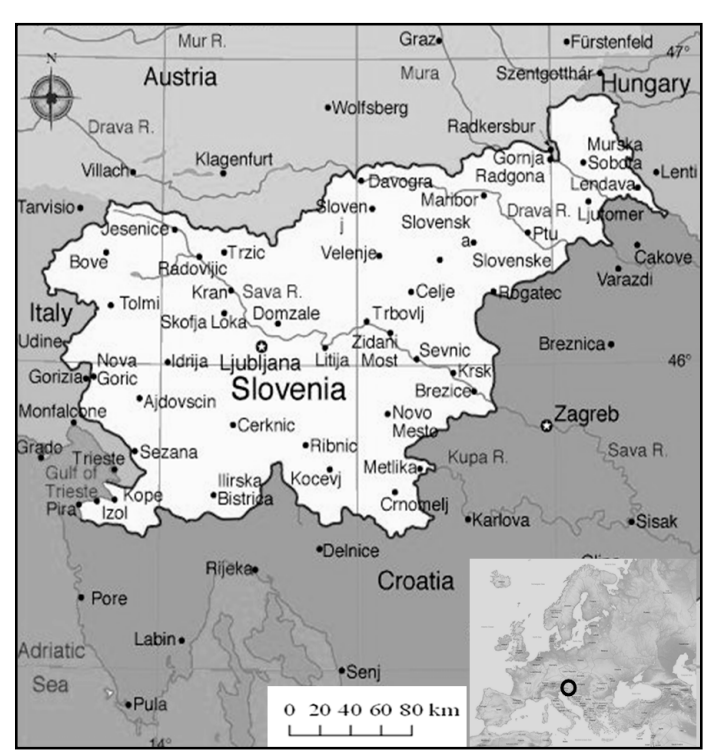

(b)

Figure 1. Analyzed study areas: (a) Serbia and (b) Slovenia (Source: Magellan Geographix, [49]). 
Table 1. Type of respondents by country (in frequencies and percentages).

\begin{tabular}{lcc}
\hline Type of Respondent from Serbia & $f$ & $\%$ \\
\hline Members of National Association “Rural Tourism of Serbia” & 46 & 22.0 \\
Members of Business Association of Hotel and Restaurant Industry in Serbia & 47 & 22.5 \\
Managers and employees from six traditional farmsteads (Dida Hornjakov salaš near Sombor, Salaš 137 in & 37 & 17.7 \\
Čenej, Majkin salaš in Palić, Katai salaš in Mali Idjoš, Cvejin salaš in Begeč and Perkov salaš near Neradin) & 9 & 4.3 \\
Managers and employees from Panacomp Rural Hospitality Net and Magelan Travel Agency & 29 & 13.9 \\
Members of Association “UGONS 1946” & 41 & 19.6 \\
Members of Association of Tourists Guides of City of Novi Sad & 209 & 100 \\
Total & $f$ & $\%$ \\
\hline Type of Respondent from Slovenia & 27 & 20.3 \\
\hline Members of Slovenian Tourist Guides & 32 & 24.1 \\
Members of Association of Tourists Agencies of Slovenia & 42 & 31.6 \\
Members of National Tourists Association-NTA & 32 & 24.1 \\
Members of International Tourism Institute and Association of Tourists Farms of Slovenia & 133 & 100 \\
Total & & \\
\hline
\end{tabular}

Table 2. Respondents' characteristics (Total $n=342$ ).

\begin{tabular}{|c|c|c|c|c|}
\hline & \multicolumn{2}{|c|}{ Serbia $n=209$} & \multicolumn{2}{|c|}{ Slovenia $n=133$} \\
\hline & $f$ & $\%$ & $f$ & $\%$ \\
\hline \multicolumn{5}{|c|}{ Gender } \\
\hline Male & 111 & 53.1 & 78 & 58.6 \\
\hline Female & 98 & 46.9 & 55 & 41.4 \\
\hline \multicolumn{5}{|c|}{ Age } \\
\hline $15-24$ & 0 & 0 & 4 & 3.0 \\
\hline $25-34$ & 37 & 17.7 & 4 & 3.0 \\
\hline $35-44$ & 102 & 48.8 & 59 & 44.4 \\
\hline $45-54$ & 62 & 29.7 & 61 & 45.9 \\
\hline $55-64$ & 6 & 2.9 & 3 & 2.3 \\
\hline$>65$ & 2 & 1.0 & 2 & 1.5 \\
\hline \multicolumn{5}{|c|}{ Educational level } \\
\hline Elementary school & 0 & 0 & 0 & 0 \\
\hline High school & 34 & 16.3 & 1 & 0.8 \\
\hline College & 97 & 46.4 & 69 & 51.9 \\
\hline Faculty & 65 & 31.1 & 52 & 39.1 \\
\hline M.Sc./Ph.D. studies & 13 & 6.2 & 11 & 8.3 \\
\hline \multicolumn{5}{|c|}{ Average monthly income } \\
\hline$<200 €$ & 0 & 0 & 0 & 0 \\
\hline $201-500 €$ & 135 & 64.6 & 0 & 0 \\
\hline $501-1000 €$ & 18 & 8.6 & 2 & 1.5 \\
\hline$>1001 €$ & 0 & 0 & 100 & 75.2 \\
\hline Incomplete responses & 56 & 26.8 & 31 & 23.3 \\
\hline \multicolumn{5}{|c|}{ Profession } \\
\hline Student & 0 & 0 & 0 & 0 \\
\hline Full time job & 185 & 88.5 & 133 & 100 \\
\hline Part time job & 24 & 11.5 & 0 & 0 \\
\hline Retired & 0 & 0 & 0 & 0 \\
\hline
\end{tabular}

Comparative analysis may position rural tourism of Serbia regarding Slovenia with which it shares numerous geographical, demographical, and other similar characteristics [50,51]. Along with this, it will be extremely useful to make a comparison of economic indicators in rural areas of both selected countries (Table 3). 
Table 3. Comparative analysis of the rural tourism development in Serbia and Slovenia in 2016.

\begin{tabular}{ccc}
\hline Components & Serbia & Slovenia \\
\hline Rural area (\% of the total territory) & $85 \%$ & $90 \%$ \\
Rural population (\% of the total population) & $48 \%$ & $57 \%$ \\
Population density in rural areas (inhabitants $/ \mathrm{km}^{2}$ ) & 84 & 102 \\
Mean unemployment rate in rural areas & $21 \%$ & $9 \%$ \\
Number of households offering tourism services & 300 & 600 \\
Mean annual number of overnight stays & 150,000 & 300,000 \\
Mean length of stay (days) & 2.8 & 3.7 \\
Total accommodation capacities (number of beds) & 8000 & 6000 \\
Mean utilization of capacities & $40 \%$ & $70 \%$ \\
Mean profit per a household (annual in Euros) & 2500 & 10,000 \\
\hline
\end{tabular}

Source: Statistical Office of The Republic of Serbia [52] and Statistical Office of Slovenia [53].

Comparative analysis of economic indicators may lead to the suggestion that both countries have similar percentages of rural territories, however with different levels of development (Table 3). Rural population percentage is larger in Slovenia with $57 \%$, and, moreover, Slovenian population density is higher [54]. According to mean unemployment rate in rural areas, critical situation is observed in Serbia with about $21 \%$ of the unemployed. Slovenia also leads in the number of households that offer tourism services with 600 households and over 300,000 annual overnight stays regarding Serbia, with only 300 households and 150,000 annual overnight stays. Furthermore, the length of stay for tourist visiting rural areas is longer for Slovenia with 3.7 days, whereas for Serbia, the number is only 2.8 days. The higher utilization of accommodation capacities is recorded for Slovenia, $70 \%$, whereas the utilizations significantly lower, only $40 \%$. Mean profit values per a household are higher for Slovenia (10,000 Euros) and lower in Serbia (2500 Euros). The results provide strong empirical support for the inclusion of rural tourism destination attributes in studies of tourism competitiveness.

The first step in the further analysis was to look at some basic descriptive statistics (arithmetic means and standard deviations) of these responses. The second step will involve the connection among the selected factors, which will be expressed by Pearson's $r$ statistical correlation, since it deals with the continuous (interval) variables. The collected sample satisfies the basic conditions for the application of parametric test, i.e., the data used in the analyses originate from the interval scale, and they are distributed normally and assess linear relationships. These frequency distributions clearly indicate one important aspect of the answers given: Slovenian responders gave consistently higher ratings than the respondents from Serbia. The SPSS 18.0 standard package for personal computers was used for data processing.

\section{Results and Discussion}

\subsection{Descriptive Statistical Analysis Findings}

Supporting factors refer to general infrastructures, quality of service, accessibility, hospitality, and market ties [21]. Some of those factors displayed in Table 4, showing potential competitiveness, while the rest display averages below 3.00 .

Modest knowledge and the absence of supplementary skills in rural population have been confirmed by the data according to which $97 \%$ of the rural population in Serbia failed to attend skills training programs and $54 \%$ of the rural population lacks special knowledge and skills [5]. Such results are unfavorable for the total capacity and competitiveness of the labor force in rural areas. Low quality of this force may be observed as one of the burdening factors in economic development of rural areas, since it causes low entrepreneur potential of rural population, as well as low economic interest of foreign investors [55]. Statistical data in rural tourism are based on estimations both for capacities and turnover [48]. Since rural areas in Serbia account for $85 \%$ of the territory, significant number of overnight stays realized in rural areas, such as mountain and spa areas [29], as well as in other tourism 
or non-tourism places may be recorded as the overnight stays in this tourism segment. Despite the relatively low averages of variables among supporting factors that are observed in Table 4, the most competitive indicator is hospitality.

Table 4. Mean and standard deviations (SD) for supporting factors for Serbia and Slovenia.

\begin{tabular}{|c|c|c|c|c|c|}
\hline \multirow{2}{*}{\multicolumn{2}{|c|}{ Competitiveness Indicators }} & \multicolumn{2}{|c|}{ Serbia } & \multicolumn{2}{|c|}{ Slovenia } \\
\hline & & Mean & SD & Mean & SD \\
\hline SF1 & Friendliness of residents towards tourists. & 3.35 & 0.819 & 4.21 & 0.970 \\
\hline$S F 2$ & Distance/flying time to destination. & 3.84 & 0.686 & 4.10 & 0.912 \\
\hline SF3 & Ease of communication between residents and tourists. & 4.52 & 0.589 & 4.44 & 0.899 \\
\hline SF4 & Financial institution and currency exchange facilities. & 2.09 & 0.761 & 3.51 & 0.974 \\
\hline SF5 & Telecommunication system. & 3.84 & 0.748 & 4.92 & 0.471 \\
\hline SF6 & Resident support for the tourism industry. & 2.24 & 0.658 & 4.70 & 0.603 \\
\hline SF7 & Ease/cost of obtaining entry Visa. & 2.48 & 0.760 & 4.32 & 0.744 \\
\hline SF8 & Ethnic ties with major tourist origin markets. & 2.93 & 0.690 & 4.53 & 0.774 \\
\hline SF9 & Ease of combining travel to destination. & 4.19 & 0.611 & 4.30 & 0.738 \\
\hline SF10 & Awareness of tourism employees about quality of services. & 3.42 & 0.743 & 4.67 & 0.660 \\
\hline SF11 & Sporting links with major tourist origin markets. & 2.93 & 0.784 & 4.38 & 0.725 \\
\hline SF12 & Health/medical facilities to serve tourists. & 4.10 & 0.567 & 4.29 & 0.734 \\
\hline SF13 & Business ties/trade links with major tourist origin markets. & 2.44 & 0.625 & 3.89 & 0.794 \\
\hline SF14 & Tourism companies have programs to ensure/monitor visitors' satisfaction. & 3.35 & 0.909 & 4.52 & 0.670 \\
\hline SF15 & Adequacy of infrastructure. & 2.31 & 0.652 & 4.64 & 0.620 \\
\hline SF16 & Local transport systems. & 1.93 & 0.744 & 4.37 & 0.764 \\
\hline SF17 & Existence of resident hospitality development programs. & 3.29 & 0.885 & 4.49 & 0.745 \\
\hline SF18 & Development of training programs to enhance quality of service. & 2.83 & 0.609 & 4.58 & 0.809 \\
\hline SF19 & Waste disposal. & 2.08 & 0.817 & 3.72 & 0.932 \\
\hline SF20 & Tourism/hospitality companies have well defined performance standards. & 1.99 & 0.658 & 4.08 & 0.785 \\
\hline
\end{tabular}

It is estimated that about 300 rural households with 8000 beds offer services and realize over 150,000 overnights annually [5]. There are estimations that each household that is involved in rural tourism has an annual profit of 5000 Euros. The households with luxury accommodation and better offer may reach annual profit of 12,000 Euros. This leads to a conclusion that rural tourism is a service strictly oriented activity that is dependent upon interaction, contact, and communication with visitors.

Adversely to Serbia, Slovenia raised tourism services to a higher level (Table 4). According to the type and content of tourism services, Slovenia legally defined three types of farm-stays: open door farms, tourist farms, and wineries. Quality classification system is determined by one, two, three, and four apples (stars). Categorization is performed when all of the conditions for the start of a farm-stays are met. Although they can boast with guests staying for two months, the present trend indicates shorter stays [42]. Weekends are booked throughout the year, which indicates that there is no high and low season.

Demanding factors involve destination image/perception and awareness of tourism products (Table 5). Survey participants determined Serbian and Slovenian overall competitiveness perception as being competitive, although only one variable averaged below 3.00 (destination image and perception in the world).

Table 5. Mean and standard deviations for demanding factors for Serbia and Slovenia.

\begin{tabular}{|c|c|c|c|c|c|}
\hline \multirow{2}{*}{\multicolumn{2}{|c|}{ Competitiveness Indicators }} & \multicolumn{2}{|c|}{ Serbia } & \multicolumn{2}{|c|}{ Slovenia } \\
\hline & & Mean & SD & Mean & SD \\
\hline DF1 & Overall perception of country as a tourism destination. & 4.16 & 0.548 & 4.65 & 0.618 \\
\hline DF2 & Destination awareness. & 3.92 & 0.678 & 4.53 & 0.634 \\
\hline DF3 & Awareness of tourism products of country abroad. & 4.18 & 0.530 & 4.84 & 0.534 \\
\hline DF4 & Destination image and perception in the world. & 2.39 & 0.700 & 4.78 & 0.569 \\
\hline
\end{tabular}

\subsection{Statistical Correlation Findings}

In order to demonstrate relations between the obtained factors $S F(1-20)-D F(1-4)$, the authors have applied the Pearson $r$ statistical correlation (Table 6). As Cohen [56] stated, the gained values in 
Pearson's $r$ correlation can present: low correlation $(r=0.10-0.29)$; middle correlation $(r=0.30-0.49)$; and, high correlation $(r=0.50-1.00)$. According to the results shown in Table 6 , it can be noticed that all of the prevailed correlation between the observed factors are positive, and that low, middle, and high correlations have been obtained in several cases. In the case of this discussion, it is important to note that only the high correlations, i.e., those that exceed the value $\geq 0.50$, will be involved in the further text, because these relations show statistically the most significant differences. Moreover, all of the analyzed outputs indicate that Slovenian respondents gave higher average marks in comparison to Serbian, which is in accordance to the current economic situations in the observed countries and our research prospects.

From the correlation pattern, it is concluded that the positive correlation of the high strength is between DF1 and SF1 $(r=0.58 ; 0.76)$, SF2 $(r=0.67 ; 0.71), S F 3(r=0.72 ; 0.79), S F 6(r=0.77 ; 0.83), S F 12$ $(r=0.71 ; 0.92)$, SF15 $(r=0.78 ; 0.86)$, SF16 $(r=0.63 ; 0.74)$, SF19 $(r=0.52 ; 0.53)$, and SF20 $(r=0.61 ; 0.66)$. These mean that the overall perception of country as a tourism destination shows a high positive correlation with the friendliness of residents towards visitors, distance/flying time to destination, ease of communication between residents and visitors, residents' support for the travel industry, health/medical facilities to serve visitors, adequacy of infrastructure, local transport systems, waste disposal, and tourism/hospitality companies have well defined performance standards. This leads to the conclusion that the preferable the general opinion and the attitude of individuals, the community and the rural stakeholders about tourist development in a destination is, the better the general perception about the same destination will be on a higher level. Dwyer et al. [43] tested the same model with stakeholders in the South Korean and Australian travel industry. Their findings underlined the fact that the examinees did not distinguish between destination management activities that are primarily the responsibility of the public sector and those that are the responsibility of the private sector. Moreover, government commitment was distinguished as a separate factor, referring to a need for an active government role in facilitating development of tourism destination in rural or urban settings.

Table 6. The average Pearson's $r$ on the relation level $S F(1-20)-D F(1-4)(p<0.01$ (2-tailed)).

\begin{tabular}{lllllllll}
\hline & \multicolumn{2}{c}{ DF1 } & \multicolumn{2}{c}{ DF2 } & \multicolumn{2}{c}{ DF3 } & \multicolumn{2}{c}{ DF4 } \\
\cline { 2 - 9 } & SRB & SLO & SRB & SLO & SRB & SLO & SRB & SLO \\
\hline SF1 & 0.88 & 0.89 & 0.24 & 0.44 & 0.24 & 0.44 & 0.52 & 0.66 \\
SF2 & 0.67 & 0.71 & 0.28 & 0.39 & 0.28 & 0.39 & 0.22 & 0.31 \\
SF3 & 0.72 & 0.79 & 0.88 & 0.92 & 0.88 & 0.92 & 0.21 & 0.23 \\
SF4 & 0.33 & 0.41 & 0.24 & 0.27 & 0.24 & 0.27 & 0.21 & 0.44 \\
SF5 & 0.22 & 0.22 & 0.14 & 0.29 & 0.14 & 0.29 & 0.48 & 0.49 \\
SF6 & 0.77 & 0.83 & 0.21 & 0.44 & 0.21 & 0.44 & 0.21 & 0.28 \\
SF7 & 0.10 & 0.24 & 0.17 & 0.21 & 0.17 & 0.21 & 0.19 & 0.22 \\
SF8 & 0.13 & 0.19 & 0.11 & 0.22 & 0.21 & 0.31 & 0.52 & 0.81 \\
SF9 & 0.48 & 0.48 & 0.54 & 0.66 & 0.54 & 0.66 & 0.24 & 0.31 \\
SF10 & 0.31 & 0.36 & 0.25 & 0.41 & 0.25 & 0.41 & 0.11 & 0.23 \\
SF11 & 0.14 & 0.24 & 0.21 & 0.44 & 0.21 & 0.44 & 0.25 & 0.44 \\
SF12 & 0.71 & 0.92 & 0.14 & 0.21 & 0.14 & 0.21 & 0.17 & 0.24 \\
SF13 & 0.43 & 0.48 & 0.72 & 0.76 & 0.72 & 0.76 & 0.26 & 0.26 \\
SF14 & 0.24 & 0.27 & 0.21 & 0.31 & 0.21 & 0.31 & 0.31 & 0.35 \\
SF15 & 0.78 & 0.86 & 0.17 & 0.21 & 0.17 & 0.21 & 0.28 & 0.36 \\
SF16 & 0.63 & 0.74 & 0.15 & 0.18 & 0.15 & 0.18 & 0.21 & 0.22 \\
SF17 & 0.33 & 0.43 & 0.21 & 0.44 & 0.21 & 0.44 & 0.20 & 0.29 \\
SF18 & 0.21 & 0.35 & 0.18 & 0.24 & 0.18 & 0.24 & 0.33 & 0.46 \\
SF19 & 0.52 & 0.53 & 0.24 & 0.33 & 0.24 & 0.33 & 0.17 & 0.21 \\
SF20 & 0.61 & 0.66 & 0.68 & 0.77 & 0.68 & 0.77 & 0.81 & 0.82 \\
\hline
\end{tabular}

The other correlations show very interesting situation. Eventually, both DF2 and DF3 show the same values of the correlations with the observed factors: SF3 $(r=0.88 ; 0.92)$, SF9 $(r=0.54 ; 0.66)$, SF13 $(r=0.72 ; 0.76)$ and SF20 $(r=0.68 ; 0.77)$. These results can be explained by the fact that the 
formulations are very similar in the questionnaire, and that respondents were not aware of the significant distinctions between these two categories. The findings underline the fact that destination awareness, as well as the awareness of tourism products of country abroad positive correlate with high values to easiness of communication between residents and visitors, business ties/trade links with major tourist origin markets, easiness of combining travel to destination and with tourism/hospitality companies, which have well defined performance standards. According to that, it can be stated that the higher the awareness of tourism products of country abroad is, the general opinion about tourist development, which produces the feeling of benefits of tourist activity in the rural area, rises. Moreover, Cracolici and Nijkamp [57] claimed that the local resources of a destination correlate only with comparative advantage of a tourist destination, incl. awareness of the product or service. Competitive advantage can only be created by improving responsiveness to demand side challenges, which calls for a relevant role of destination management [44]. Tourism destination policy is also regarded to be under the responsibility of all public actors [58], whose main aim would be to "create an environment that provides maximum benefit to the stakeholders of the region while minimizing negative impacts" (p. 148), which will contribute to the better destination image and has significant impact on its awareness.

From the last correlation pattern, it is concluded that the positive correlation of the high strength is between DF4 and SF1 $(r=0.88 ; 0.89)$, SF8 $(r=0.52 ; 0.81)$, and SF20 $(r=0.81 ; 0.82)$. The findings indicate the fact that destination image and perception in the world positive correlate with high values with friendliness of residents towards visitors, ethnic ties with major tourist origin markets and tourism/hospitality companies have well defined performance standards. This can be interpreted that the image and perception of the destination is tightly connected with the attitude of the locals, cultural and ethnic connections with the homeland and directly with the hotels and other types of tourism organizations, which provide direct services to the visitors. Moreover, the results obtained by Woosnam [59] showed that concern for local tourist development highly positive correlates $(r=0.52)$ with the benefits that local community has from tourist development. Together with this, Wilson et al. [23] examined the factors that have helped rural communities to successfully develop image of tourism, which is highly correlated with their entrepreneurship opportunities. Their results clearly indicated high correlation between the relevance of a community approach and their perception and the role of entrepreneurs in the development of rural tourism destinations. The same authors proposed conditions for successful rural tourism destination development, involving: support and participation of local government, coordination between rural tourism entrepreneurs, sufficient funds for tourism development, good community leadership, information and technical assistance for tourism development and promotion, widespread community support for tourism, and so on. Most of these conditions are mutually connected and make complementary unit in order to improve destination competitiveness of tourism product in rural area.

\section{Conclusions}

Rural tourism stakeholders across the various state sectors of Slovenian and Serbian rural tourism evaluated how important these actions were to the industry's future development and their performance in respect of these actions. In the last decades, Serbian rural tourism has not achieved a high level of development, which resulted in low competitiveness in the international travel market. Nevertheless, current rural development in Serbia is defined as one of the main economic priorities by the National Government. The diversification of the rural economy to an ecological, economic, and socially sustainable form aims to improve the quality of locals' life, reduce poverty, and social and environmental degradation. These goals are focused primarily on the sustainable environmental protection and the development of a local-global partnership. Even today, Serbia still does not achieve relevant results in rural tourism globally, because with approximately 8000 accommodation capacities in mainly old and unequipped buildings, it cannot receive the approximate commercial results that competitors have achieved. Therefore, the current level of competitiveness in the rural tourism 
sector in Serbia is far from good, although there are natural, cultural, and social preconditions for its development: active labor force in agriculture, agricultural land, excellent potential for agritourism, unpolluted soil, and the possibility of organic food growth.

On the other side, well-arranged and highly developed rural tourism in Slovenia contributes not only to better profit gain by households, but also to sustainable development of rural areas, diversity of tourism offers, and improving the quality of the locals' living in a countryside. For decades, Slovenian government and local stakeholders in rural tourism have been making joint efforts to achieve the high economic level and become compared with many leading countries in rural travel industry (e.g., Austria, Italy, Germany, France, etc.).

The findings of this research provide empirical support for the causal relationships proposed between perceptions of community attachment, rural tourism development, support for multifunctional agriculture, and locals' wellbeing. Rural residents are more likely to decide to support tourism development when they more clearly perceive improvements in their quality of life. Additionally, after testing the proposed model through analyses of the data collected, a direct relationship can be said to exist between the local community attachment and perceptions of tourism's impacts in the context of tourism development in rural environments. More precisely, the results confirm that residents play a fundamental role in planning for tourism development, showing this to be applicable in the context of rural tourism offer in typical transitional societies (with daily economic transformations). The main theoretical contribution of the study is the key role that residents perform in tourism development in rural settings, even more when a type of tourism based on the local heritage, farms, rural environmental is developed, as rural tourism in the observed countries is. The benefit of this research is reflected on the knowledge of the predictors of support for tourism development, which is specifically applied in rural settings in post-socialist conditions.

As all other research studies, this one also has certain limitations. The greatest limitations are potential changes in the respondents' attitudes. In this respect, the same research should be organized in order to compare with this previous one. Together with this, we would recommend that future researches include bigger sample size and other rural settlements, where there are tourist activities with the aim to make a broader comparison. Such settlements could be not only in Serbia and Slovenia, but also in the surrounding areas and countries, where there are areas with active rural tourist activities. When writing and realizing international projects in rural tourism is concerned, a good example comes from the neighboring Balkan country-Montenegro. This country, through its international project Farm Tour for the cross-border cooperation with Albania, had the aim to connect the productions of home-made organic food with tourism, i.e., farmers and local tourist organizations of these two countries. A similar idea could also be realized in the cases of Serbia and Slovenia, which would have a task to connect into network farm-stays with similar subjects in Hungary, Croatia, Bosnia and Herzegovina, Italy, and Romania. Such networking could be realized through a creation of potential agritourist clusters or similar ways of association. Within similar projects, a motto with the title e.g., Find your host in a village (or similar) could be formulated, which would undoubtedly initiate the individualization of the households and "provoke" them to be mutually more competitive. This kind of concept could contribute to the rural destination's competitiveness, encourage the consumers to visit farms and with the payment of a symbolic tax, they could pick and try seasonal agricultural products during their stay. Thus, they would get familiar with the choice, which they are offered in shops, so that they would be able to decide about buying certain products more easily and more objectively. On the other hand, those who offer services would get a stronger motive to struggle and to prove the quality of their products of the countryside.

According to everything said, it can be concluded that the world trends in tourism strive towards rural areas and emphasize the needs and motives of modern population for the return to the natural and unpolluted environment. In such a tendency, rural tourism can become an important market segment, and by obeying the rules of sustainable development and by cherishing local tradition and 
culture, this aspect of tourism is becoming one of the strategic and most efficient ways of rural areas' development in transitional societies, such as Serbian and Slovenian.

Acknowledgments: The research was supported by Ministry of Education, Science and Technological Development, Republic of Serbia (Grant III 47007) and by the Act 211 Government of the Russian Federation, contract No. 02.A03.21.0011.

Author Contributions: Marko D. Petrović, Aleksandra Vujko and Tamara Gajić designed the research and applied the survey in Serbia and in one part of Slovenia (eastern part); Darko B. Vuković and Natalia Vuković applied the survey in Slovenian territories excluded in the first part of the research (central and southern parts) and Jasmina Jovanović in the northern part of Slovenia; Milan Radovanović, Darko B. Vuković and Jasmina Jovanović organized the data bases; Milan Radovanović and Natalia Vuković analyzed the data. Marko D. Petrović, Aleksandra Vujko and Tamara Gajić wrote the paper.

Conflicts of Interest: The authors declare no conflict of interest.

\section{References}

1. Horakova, H. Post-Communist Transformation of Tourism in Czech Rural Areas: New Dilemmas. Anthropol. Noteb. 2010, 16, 59-77.

2. Leanza, P.; Porto, S.; Sapienza, V.; Cascone, S.A. Heritage Interpretation-Based Itinerary to Enhance Tourist Use of Traditional Rural Buildings. Sustainability 2016, 8, 47. [CrossRef]

3. Bilbao-Terol, C.; Cañal-Fernández, V.; Valdés, L.; Del Valle, E. Rural Tourism Accommodation Prices by Land Use-Based Hedonic Approach: First Results from the Case Study of the Self-Catering Cottages in Asturias. Sustainability 2017, 9, 1688. [CrossRef]

4. National Sustainable Development Strategy (Serbia). 2007. Available online: http://www.un.org/esa/ agenda21/natlinfo/countr/serbia/nsds_serbia.pdf (accessed on 11 August 2017).

5. Petrović, M.D.; Blešić, I.; Ivolga, A.; Vujko, A. Agritourism Impact toward Locals' Attitudes-An Evidence from Vojvodina Province (Serbia). J. Geogr. Inst. Jovan Cvijić SASA 2016, 66, 105-123. [CrossRef]

6. Koscak, M. Integral Development of Rural Areas, Tourism and Village Renovation, Trebnje, Slovenia. Tour. Manag. 1998, 19, 81-85. [CrossRef]

7. Erjavec, E.; Rednak, M.; Volk, T. The European Union enlargement-The case of agriculture in Slovenia. Food Policy 1998, 23, 395-409. [CrossRef]

8. Knežević, A.A.; Cvelbar, L.J. Privatization, Market Competition, International Attractiveness, Management Tenure and Hotel Performance: Evidence from Slovenia. Int. J. Hosp. Manag. 2011, 30, 391-397. [CrossRef]

9. Lock, K.; Gabrijelcic-Blenkus, M.; Martuzzi, M.; Otorepec, P.; Kuhar, A.; Robertson, A.; Wallace, E.; Dora, C.; Maucec Zakotnic, J. Conducting an HIA of the Effect of Accession to the European Union on National Agriculture and Food Policy in Slovenia. Environ. Impact Assess. Rev. 2004, 24, 177-188. [CrossRef]

10. Dwyer, L.; Knežević Cvelbar, L.J.; Edwards, D.; Mihalič, T. Fashioning a Destination Tourism Future: The Case of Slovenia. Tour. Manag. 2012, 33, 305-316. [CrossRef]

11. Estol, J.; Font, X. European Tourism Policy: Its Evolution and Structure. Tour. Manag. 2016, 52, $230-241$. [CrossRef]

12. Armenski, T.; Gomezelj, D.; Djurdjev, B.; Ćurčić, N.; Dragin, A. Tourism Destination Competitiveness-Between Two Flags. Econ. Res. Ekon. Istraž. 2012, 25, 485-502. [CrossRef]

13. Potočnik-Slavič, I.; Schmitz, S. Farm Tourism across Europe. Eur. Countrys. 2013, 4, 265-274. [CrossRef]

14. Everett, S.; Aitchison, C. The Role of Gastronomy Tourism in Sustaining Regional Identity: A Case Study of Cornwall, South West England. J. Sustain. Tour. 2008, 16, 150-167. [CrossRef]

15. Ursache, M. Tourism-Significant Driver Shaping a Destinations Heritage. Procedia Soc. Behav. Sci. 2015, 188, 130-137. [CrossRef]

16. Demirović, D.; Petrović, M.D.; Neto Monteiro, L.C.; Stjepanović, S. An Examination of Competitiveness of Rural Tourism Destinations from the Supply Side Perspective-Case of Vojvodina (Serbia). J. Geogr. Inst. Jovan Cvijić SASA 2016, 66, 387-400. [CrossRef]

17. Petrović, M.D.; Lukić, D.; Radovanović, M.; Vujko, A.; Gajić, T.; Vuković, D. “Urban geosites” as potential geotourism destinations-Evidence from Belgrade. Open Geosci. 2017, 9, 442-456. [CrossRef]

18. Komppula, R. The Role of Individual Entrepreneurs in the Development of Competitiveness for a Rural Tourism Destination-A Case Study. Tour. Manag. 2014, 40, 361-371. [CrossRef] 
19. Villanueva-Álvaro, J.; Mondéjar-Jiménez, J.; Sáez-Martínez, F. Rural Tourism: Development, Management and Sustainability in Rural Establishments. Sustainability 2017, 9, 818. [CrossRef]

20. Campón-Cerro, A.; Folgado-Fernández, J.; Hernández-Mogollón, J. Rural Destination Development Based on Olive Oil Tourism: The Impact of Residents' Community Attachment and Quality of Life on Their Support for Tourism Development. Sustainability 2017, 9, 1624. [CrossRef]

21. Dwyer, L.; Kim, C. Destination Competitiveness: Determinants and Indicators. Curr. Issues Tour. 2003, 6, 369-414. [CrossRef]

22. Lane, B.; Kastenholz, E. Rural tourism: The evolution of practice and research approaches-Towards a new generation concept? J. Sustain. Tour. 2015, 23, 1133-1156. [CrossRef]

23. Wilson, S.; Fesenmaier, D.R.; Fesenmaier, J.; Van Es, J.C. Factors for success in rural tourism development. J. Travel Res. 2001, 40,132-138. [CrossRef]

24. Hall, D. Rural tourism development in southeastern Europe: Transition and the search for sustainability. Int. J. Tour. Res. 2004, 6, 165-176. [CrossRef]

25. Sharpley, R. Rural tourism and the challenge of tourism diversification: The case of Cyprus. Tour. Manag. 2002, 23, 233-244. [CrossRef]

26. Petrick, M.; Gramzow, A. Harnessing Communities, Markets and the State for Public Goods Provision: Evidence from Post-Socialist Rural Poland. World Dev. 2012, 40, 2342-2354. [CrossRef]

27. Mikulcak, F.; Haider, J.L.; Abson, D.J.; Newig, J.; Fischer, J. Applying a Capitals Approach to Understand Rural Development Traps: A Case Study from Post-Socialist Romania. Land Use Policy 2015, 43, 248-258. [CrossRef]

28. Petrović, M.D.; Blešić, I.; Vujko, A.; Gajić, T. The Role of Agritourism's Impact on the Local Community in a Transitional Society: A Report from Serbia. Transylv. Rev. Adm. Sci. 2017, 13, 146-163. [CrossRef]

29. Petrović, M.D.; Gelbman, A.; Demirović, D.; Gagić, S.; Vuković, D. The Examination of the Residents' Activities and Dedication to the Local Community-An Agritourism Access to the Subject. J. Geogr. Inst. Jovan Cvijić SASA 2017, 67, 37-52. [CrossRef]

30. Light, D. 'Facing the Future': Tourism and Identity-Building in Post-Socialist Romania. Political Geogr. 2001, 20, 1053-1074. [CrossRef]

31. Williams, M.A.; Balaž, V. The Czech and Slovak Republics: Conceptual Issues in the Economic Analysis of Tourism in Transition. Tour. Manag. 2002, 23, 37-45. [CrossRef]

32. Herrschel, T. Between Difference and Adjustment-The Re-/Presentation and Implementation of Post-Socialist (Communist) Transformation. Geoforum 2007, 38, 439-444. [CrossRef]

33. Săvoiu, G.; Ţaicu, M. Foreign Direct Investment Models, Based on Country Risk for Some Post-Socialist Central and Eastern European Economies. Procedia Econ. Financ. 2014, 10, 249-260. [CrossRef]

34. Zeković, S.; Vujošević, M.; Maričić, T. Spatial Regularization, Planning Instruments and Urban Land Market in a Post-Socialist Society: The Case of Belgrade. Habitat Int. 2015, 48, 65-78. [CrossRef]

35. Vujko, A.; Gajić, T. Opportunities for Tourism Development and Cooperation in the Region by improving the Quality of Supply-The “Danube Cycle Route" Case Study. Econ. Res. Ekon. Istraž. 2014, 27, 847-860. [CrossRef]

36. Blaine, T.W.; Mohammad, G.; Var, T. Demand for Rural Tourism: An Exploratory Study. Ann. Tour. Res. 1993, 20, 770-773. [CrossRef]

37. Sznajder, M.; Przezbórska, L.; Scrimgeour, F. Agritourism; CABI Publishing: Wallingford, UK, 2009.

38. Todorović, M.; Bjeljac, Ž. Rural Tourism in Serbia as a Concept of Development in Undeveloped Regions. Acta Geogr. Slov. 2009, 49, 453-473. [CrossRef]

39. EuroGites-European Federation of Rural Tourism. Available online: http://eurogites.org/documents/ (accessed on 16 December 2017).

40. Knickel, K.; Renting, H. Methodological and Conceptual Issues in the Study of Multifunctionality and Rural Development. Sociol. Rural. 2000, 40, 512-528. [CrossRef]

41. Ohe, Y. Multifunctionality and rural tourism: A perspective on farm diversification. J. Int. Farm Manag. 2007, 4, 1-23.

42. Petrović, M.D.; Radović, G.; Terzić, A. An Overview of Agritourism Development in Serbia and European Union Countries. Int. J. Sustain. Econ. Manag. (IJSEM) 2015, 4, 1-14. [CrossRef]

43. Dwyer, L.; Mellor, R.; Livaic, Z.; Edwards, D.; Kim, C.W. Attributes of Destination Competitiveness: A Factor Analysis. Tour. Anal. 2004, 9, 91-101. [CrossRef] 
44. Gomezelj, O.D.; Mihalič, T. Destination Competitiveness-Applying Different Models, the Case of Slovenia. Tour. Manag. 2008, 29, 294-307. [CrossRef]

45. Dragićević, V.; Jovičić, D.; Blešić, I.; Stankov, U.; Bošković, D. Business Tourism Destination Competitiveness: A Case of Vojvodina Province (Serbia). Econ. Res. Ekon. Istraž. 2012, 25, 311-331. [CrossRef]

46. Chin, C.H.; Lo, M.C.; Songan, P.; Nair, V. Rural Tourism Destination Competitiveness: A Study on Annah Rais Longhouse Homestay, Sarawak. Procedia Soc. Behav. Sci. 2014, 144, 35-44. [CrossRef]

47. Mulec, I.; Wise, N. Indicating the Competitiveness of Serbia's Vojvodina Region as an Emerging Tourism Destination. Tour. Manag. Perspect. 2013, 8, 68-79. [CrossRef]

48. Vujko, A.; Petrović, M.D.; Dragosavac, M.; Gajić, T. Differences and Similarities among Rural Tourism in Slovenia and Serbia-Perceptions of Local Tourism Workers. Ekon. Poljopr. Econ. Agric. 2016, 63, 1459-1469. [CrossRef]

49. Magellan Geographix. Available online: https://www.pinterest.com/geographylovin/europe-geography/ (accessed on 22 November 2017).

50. Rey, V.; Groza, O. Balkans. In International Encyclopedia of Human Geography; Kitchin, R., Thrift, N., Eds.; Elsevier: Amsterdam, The Netherlands, 2009; pp. 265-272.

51. Grum, B.; Kobal Grum, D. Satisfaction with Current Residence Status in Comparison with Expectations of Real Estate Buyers in Slovenia and Serbia. Procedia Soc. Behav. Sci. 2014, 109, 263-275. [CrossRef]

52. Statistical Office of the Republic of Serbia (SORS, 2017). Available online: http://www.stat.gov.rs/website/ public/pageview.aspx?pkey=180 (accessed on 30 May 2017).

53. Statistical Office of Slovenia (SURS, 2017). Available online: http://pxweb.stat.si/pxweb/database/ economy/economy.asp (accessed on 2 June 2017).

54. Šprah, L.; Novak, T.; Fridl, J. The Wellbeing of Slovenia's Population by Region: Comparison of Indicators with an Emphasis on Health. Acta Geogr. Slov. 2014, 54, 67-87. [CrossRef]

55. Hall, R.D. Tourism Development and Sustainability Issues in Central and South-Eastern Europe. Tour. Manag. 1998, 19, 423-431. [CrossRef]

56. Cohen, J. Statistical Power Analysis for the Behavioral Sciences, 2nd ed.; Lawrence Erlbaum Associates Publishers: New York, NY, USA, 1988.

57. Cracolici, M.F.; Nijkamp, P. The attractiveness and competitiveness of tourist destinations: A study of Southern Italian Regions. Tour. Manag. 2009, 30, 336-344. [CrossRef]

58. Ritchie, J.R.B.; Crouch, G.I. The Competitive Destination. A Sustainable Tourism Perspective; CABI Publishing: Oxon, UK, 2003.

59. Woosnam, K.M. Using Emotional Solidarity to explain residents' attitudes about tourism and tourism development. J. Travel Res. 2012, 51, 315-327. [CrossRef] 